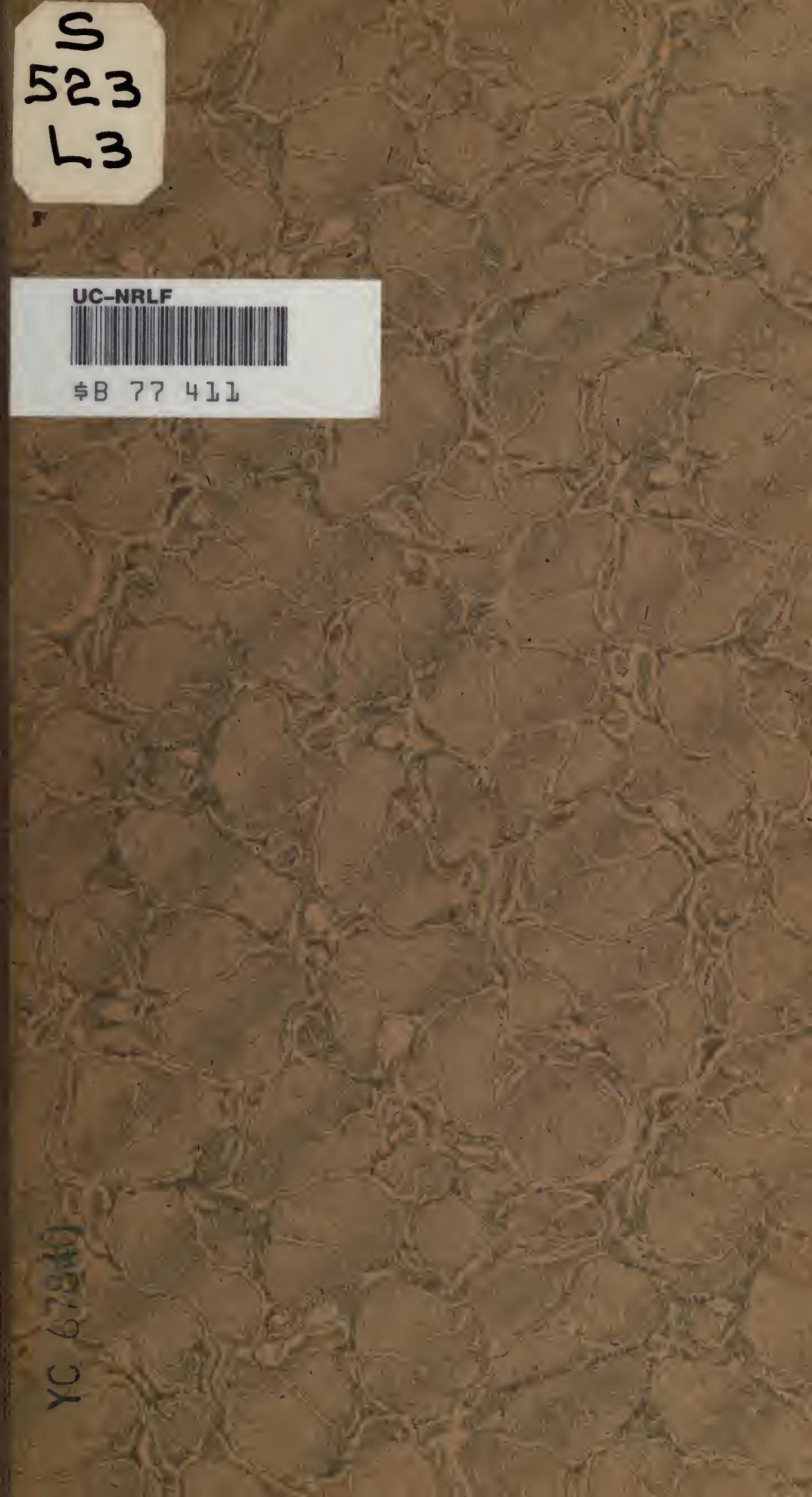




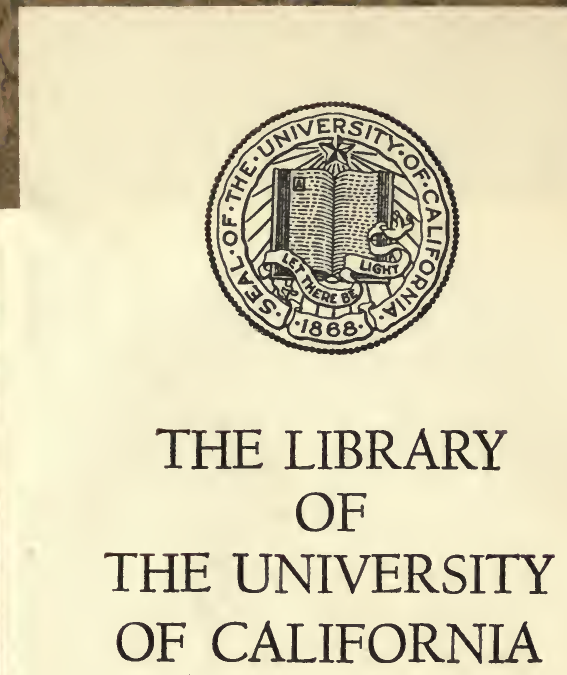

PRESENTED BY

PROF. CHARIES A. KOFOID AND MRS. PRUDENCE W. KOFOID

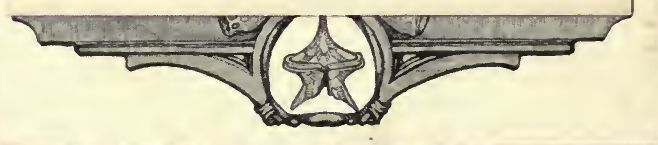




\section{A DDRESS}

DELIVERED BEFORE THE

\section{HAMPSHIRE, FRANKLIN AND HAMPDEN}

\section{AGRICULTURAL SOCIETY,}

AT THEIR

\section{Annual Fair,}

HOLDEN AT

NORTHAMPTON, OCTOBER 24, 1832.

BY MYRON LAWRENCE.

PUBLISHED BY REQUEST.

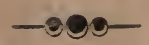

NORTHAMPTON :

JOHN METCALF, PRINTER.

1832. 



\section{3 \\ 43}

\section{ADDRESS.}

The war of the revolution left our fathers in possession of little else, than unsullied national honor, and political independence. Their energies and resources, they had unsparingly expended in achieving their emancipation. Private fortunes, and personal services were alike, freely offered on the altar of the common weal. Three millions of people, sparsely scattered through thirteen states, sustained with unbroken front, and unshrinking fortitude, for seven long years, the accumulated horrors of "war, pestilence, and famine." British power could not subdue them; British diplomacy could not ensnare them. The arts of peace, during this conflict, were necessarily neglected. The spirit of adventure was shorn of its strength, and commercial enterprise compelled to lie dormant. All national and individual resources were engaged in one direction, and made to concentrate on one grand object, the attainment of national freedom.

At the return of peace, they found themselves, indeed, politically free, but exhausted by their protracted warfare, embarrassed by an imbecile government, loaded with debt, oppressed by poverty, and distracted by domestic feuds. Who, that contemplated the young republic, at that period, struggling for existence, would have predicted her

\section{$36 \times 5 \% \bar{M}^{3} 368062$}


future greatness ? Who could have persuaded himself, that within fifty years, the descendants of that little band of patriots, would have multiplied to thirteen millions, that eleven new states would have been added to the union, and that the population of the valley of the Mississippi, then an unexplored wilderness should exceed, in number, the asserters of our independence? Incredible as the prediction might have appeared, it is more than verified by facts. The noble Mississippi rolls her fertilizing waters near two thousand miles through a country, thickly studded with settlements; which was then the undisputed possession of savages. Their council fires have become extinct, and the city, or town, or hamlet now marks the site of the chieftain's lodge.

The confederacy of the states having been superseded by our present well balanced constitution, and the government successfully organized according to its provisions, the characteristic enterprise of our citizens began to exhibit itself. The western forests fell beneath the axe of the adventurous emigrant from the Atlantic states. The fertility of the soil, and the salubrity of the climate, invited rapid settlement. Towns and villages were soon thickly planted along our western border, and plenty and comfort blessed their inhabitants. The rude hut of the Indian gave place to the comfortable dwelling, and the rustling forest to the highly cultivated field, waving with its yellow harvests. The tide of emigration still rolled onward, and these frontier towns. and villages soon became radient points, sending their inhabitants to the "far off West." The canal 
and the railroad, the steamboat and the steamcar offer their facilities for the transportation of commodities. Remote extremes are thus brought near. The mountain and the valley, the river and the lake, are alike easily passed, as if by the power of magic. The rapid currents of the great rivers of the West are ascended by the power of steam, with almost the speed of the race horse. Journeys, that required months for their accomplishment, are now performed in as many days. New Orleans and St. Louis, Detroit and Passamaquoddie, Boston and Praire du Chin, which were once regarded as at almost impassable distances, are now, for the purposes of business, neighbors. The certainty of arrival and departure, and the ease and expedition of these modern modes of conveyance, are of incalculable value to the man of business, and greatly promote the general prosperity of our country.

No flight of imagination is, perhaps, too bold, to anticipate our increase in numbers, and wealth, and power, and national resources, during the current half century. The ratio of multiplication, large as it is, will probably increase, rather than diminish. The facilities for sustaining a dense population are daily multiplying in the Atlantic states, and every acre that is reclaimed at the West, and South West, adds to the means of support. Every newly cultivated foot of ground, every loom, or spindle, increases the national wealth. Every yard of canvass; that floats in the breezes, and every ton of shipping, that swims on the waters of the ocean, contribute to swell the aggregate fund. Is it too much, then, for a sanguine imagination, indeed, is it too much for 
sober reason, to say, that our population will number its forty millions, that the pioneers of the "far off West," receding from the rich prairies, and fertile bottom lands of the Mississippi valley, will extend our frontier settlements to the Rocky mountains, perhaps, even to the gentle waters of the Pacific; that the scattered tribes of the wilderness will disappear, and the onward tide of emigration continue to roll in successive waves, till arrested by that insuperable barrier. What a picture is here presented to the view of the philanthropist and statesman. Forty millions of freemen, inhabiting a country, extending through some twenty degrees of latitude, and fifty of longitude, constituting one immense republic. Grand, and imposing, as this picture may appear, is the reality improbable? Our national debt is almost discharged, the treasury is overflowing, the national domain renders its millions annually, the ordinary revenue more than meets the usual expenditures of government. These resources, under an enlightened, and patriotic administration will be expended in facilitating intercommunication, in strengthening our national defences, and in consolidating the union. Every year adds to our united strength, and renders our political existence, as a republic, less problematical. Yet, however fair its prospects of future greatness may now appear, they may be defeated. This splendid triumph of free institutions may never be realised. The hydra, disunion, may acquire the ascendency, and this fair republic fall a sacrifice to her machinations. Nullification, and its kindred heresies may set the laws at defiance, and involve the states in 
exterminating wars. An ambitious president may nullify the legislative and judicial departments of the government, by refusing to execute the laws, and thus pave his way to despotic authority. But let us hope for better things. We have heretofore had our political agitations and strifes. More than once has the horizon been overcast with dark portentous clouds. More than once has the thunder of disunion been heard in the distance menacing the dissolution of our civil compact. But like the whirlwind and the tempest, the hail and the lightning of the physical world, they have passed off, leaving a purer atmosphere and serener sky.

In this march to national greatness, where will New-England, this little speck on the map of our country, be found? Will she be found as usual, in the van, pioneering the way of improvements, or will she abandon her love of enterprise, and retrograde to the rear? Her determination is already announced, and she has assumed an advanced position in the line of march, by encouraging manufactures and the mechanic arts. She is destined to sustain the same relation to manufactures, that she has, hitherto, sustained to commerce, and while her canvass shall continue to whiten every sea, her ships shall be freighted with the produce of her looms and workshops.

The local advantages of New-England seem to designate her as the favorite site of manufacturing establishments. Her proximity to the Atlantic, and her immediate connexion with the great internal channels of communication; her immense water - powers, and inexhaustible supplies of timber and 
fuel ; the luxuriance of her pastures, and the comparative sterility of her soil for growing grain, and other staples; the salubrity of her climate, and the density, morality, industry, and ingenuity of her population, all seem to indicate her as peculiarly fitted to embark in this enterprise.

How would the extensive introduction of cotton and woollen manufactories affect the interests of agriculture? Would it produce the result so often, and so confidently, predicted by the enemies of the system, a farther and a ruinous depression? or, would it infuse new vigor into the husbandman, and give a new impulse to agricultural pursuits? It is believed, that the legitimate tendency of the system is exactly the reverse of that predicted, and that it would materially promote the interests of the farmer, by furnishing him an additional market, and enhancing the price of his commodities. The best of all markets for the farmer's produce is a domestic one, because it gives him a quick return, and relieves him from the charges of storage and transportation. It is too obvious for comment, that many, who are now engaged in the pursuits of agriculture, would then, turn their attention to manufactures, and thus add to the number of consumers, and increase the demand for agricultural products. The more consumers, compared with the producers, the readier the market, and the greater the price. This idea of an extensive domestic market for the surplus produce of the soil; is of the first consequence. "It is of all things," says Gen. Hamilton, "that, which most effectually conduces to a flourishing state of agriculture. The establishment of man- 
ufactures is calculated, not only to increase the general stock of useful and productive labor, but to improve the state of agriculture in particular, certainly to advance the interests of those, who are engaged in it." "If a manufacture be established in any rich and fertile country, by convening a number of people in one place, who must all be fed by the farmer, without interfering with any of his necessary operations, they establish a ready market for the produce of his farm, and thus throw money into his hands, and give spirit and energy to his culture." Farmers in the immediate neighborhood of flourishing manufactories would derive an additional advantage over their fellows in the interior, by the extensive culture of culinary vegetables, a species of produce that renders most liberal profits. Those more remote would increase the profits of their farms by devoting them to the growing of wool, which would soon become a staple product, and if the business of manufacturing should prove only moderately successful, so that the mills should be kept in operation, a fair and uniform price for the article would soon be established. The fluctuations, hitherto, in the value of this product, have materially discouraged its growth. The confidence of the farmer is impaired, and his sheep are sent to the slaughter. But let woollen manufactures be sufficiently protected by government, so, at least, as to secure to them our own markets, and these ruinous speculations will cease. The farmer may then calculate, in advance, the value of his wool, with as much certainty as he now can, that of his rye and corn. His flocks would revive, and his pastures 
become again tenanted by that least expensive, and most profitable species of stock.

"Manufacturing establishments afford occasional. and extra employment to industrious individuals and families, who are willing to devote the leisure resulting from the intermissions of their ordinary pursuits, to collateral labors, as a resource for multiplying their acquisitions or enjoyments. 'I'he husbandman himself experiences a new source of profit and support from the increased industry of his wife and daughters, invited and stimulated by the demands of the neighboring manufactories."

The genial influence of their successful introduction would be felt by all landholders and cultivators in the material diminution of taxes, and the rapid rise in value of real estate. The worth of lands is proportioned to their capacity of production, and their proximity to market. If, by encouraging the growth and multiplication of these establishments, we create a market at home, in our own neighborhood, perhaps, before our own doors, who does not see, that we materially increase the value of our lands, and render their cultivation more profitable? The establishment of a home market calls into action all the energies of the husbandman, and adds new zest to agricultural pursuits.

In a moral, and political view, the general introduction of manufacturing establishments, assumes yet higher importance. The peculiar moral excellency of large manufactories, as conducted in NewEngland, is their furnishing active employment to a class of persons, who without them, have not the means of regular occupation. (Females and chil- 
dren, otherwise too often idle, are here provided with pleasant and profitable engagement. While by their industry, they are enabled to contribute essentially towards their support, and education, they are preserved entirely from the temptations of idleness, and the allurements of vice. On this subject, we are happily not without experience. Visit the flourishing manufacturing villages of Lowell, Waltham, Ware, and Chickopee, and inquire into their internal arrangement and police, and show me, if you can, more orderly, and prosperous, and happy communities. Children under a certain age are required to be kept at school, while those above that age, are employed, regular hours, in the performance of allotted easy tasks, and both, contented and happy, are acquiring temperate, industrious, and useful habits. Habit, in the conduct of life, is every thing. Children, early and systematically trained to the regular habits of application, practised in well conducted factories, will be very unlikely to depart from them in after-life, and assume the disorderly and vagabond habits of the votaries of idleness and sloth.

Politically considered, their extensive introduction is of the first consequence. They would rapidly increase our population, both by preventing emigration to the new states, and by inducing immigration to these establishments. Our own sons and daughters would give over their dreams of the valley of the Mississippi, and the verdant banks of the Ouisconsin and St. Joseph's, when they found offered them, at home, the means of easy, and reputable support. Yankee skill, and ingenuity, would 
find profitable employment in our own workshops, and manufactories, rather than in the western wilds. New-England will soon be shorn of her remaining political importance, unless her population can be more rapidly increased, so as to keep pace with the clustering thousands of the western states. Her voice may, indeed, be still heard and respected, the eloquence of her statesmen will be admired, and their arguments prove unanswerable, yet, notwithstanding, her interests will, be overlooked, and her just demands, neglected. It is a mortifying truth, but, therefore, none the less worthy to be told, that the best, and often, the only successful argument in our national councils, is numbers, mere physical force. Let us, then, by giving all proper encouragement to the establishment of manufactories among us, endeavor to acquire possession of this best, this conclusive argument.

Past experience has demonstrated the extreme folly and madness of relying on foreign countries, exclusively, for a supply of manufactures. Our late war with Great Britain found us unprovided with the necessary materials for equipping and clothing our defenders. We were compelled to trust to the spindles and looms of our enemies, for the very blankets of our soldiers. The urgent necessity of the case supplied itself by corresponding efforts. Numerous small manufactories were put in operation, in various parts of our country, and during the war, contributed materially to its successful progress, and proved profitable investments of capital. On the re-opening of our ports to foreign importations, these young establishments could not, unaided by 
government, sustain themselves against the skill, and enterprise, and wealth of British manufacturers. The comparative cheapness of production in Europe at that time, added to the settled determination of British merchants to monopolize our markets at any sacrifice, involved our unprotected establishments in utter ruin. The cotton mills, however, having received early aid, and excelling in their machinery, have been able not only to sustain themselves, but to drive the foreign manufacturer from our markets, and make large dividends on the capital invested. The manufacture of woollens proved more disastrous, and many of our most enterprising countrymen, who entered this business with bright hopes, lost both labor and capital. So far as agriculture is concerned, the establishment of woollen manufactures is far more important, than that of cotton. The cotton manufacture promotes agriculture chiefly as it furnishes an increased demand for provisions, while the woollen contributes equally to the establishment of a domestic market, and stimulates the industry of the farmer, by paying him liberally for his wool. Was the demand for wool commensurate with the capacity of our lands for producing it, the rapid increase in wealth of the New-England farmer, would be matter of astonishment even to himself.

It early became a grave question among our legislators, whether manufactures should be abandoned to their fate, or be so far protected by the imposition of discriminating duties, as to enable them to compete successfully with foreign fabrics. Much angry and intemperate discussion was elicited by 
the question. Local interests, and sectional prejudices were summoned to the combat. The cries of wanton oppression on the one hand, and of cruel and ruthless abandonment on the other, were loudly uttered. The North and the South were pitched against each other in hostile array, and sustained their respective positions with much partizan zeal. Parties in a free government are always to be expected, but that legislative measures, changing materially the national policy, should be unanimously approved by the inhabitants North of a certain geographical line, and as unanimously condemned by the inhabitants South of that line, is, indeed, "strange, passing strange." What is there in the waters of the Potomac, or in the breezes of the Alleghanies, that should produce this withering effect on our national policy? The halls of congress were beseiged, session after session, by various opposing interests, and the battle between the champions of free trade, and the American system was fraught with various success, till at the last session, a modified tariff of duties was obtained, distinctly recognizing the principle of protection to domestic industry.

It being now the avowed policy of the government to encourage the growth and production of certain manufactures, by the imposition on similar foreign articles, of other and greater duties, than are necessary for the purposes of revenue, we may expect to see large investments of capital in manufacturing stock, and an active competition among manufacturers. It has been well said, that all reasoning is in favor of free trade and unrestricted 
importation, and all facts in favor of a protecting tariff. It would seem that the imposition of a high duty for the purpose of excluding a foreign fabric, and protecting a domestic one, would necessarily enhance the price of the protected article, to the consumer. But how is the fact? Cotton goods, that sold for thirty cents per yard before a protecting duty was laid on them, are now brought into the market at twelve and an half cents, affording a fair profit to the manufacturer. Indeed, our cotton manufactures can now sustain themselves against the world, and compete successfully in any market. And what is there, in the nature of the case, to prevent woollen fabrics attaining the same success at home, and the same high character abroad ? Let the experiment be judiciously made, and who can doubt its result? American woollens have already attained to high excellence, notwithstanding the grievous embarrassments with which they have had to contend. Give them the benefit of a liberal tariff, and a settled policy, and all the arts, and wealth, of foreigners, cannot prevent their rapid increase in number and in excellence. Let the duties, however inadequate, remain undisturbed, as now settled, and confidence in the policy of the government be restored, and the manufacture of woollens can hardly fail to become a gainful business. It is the uncertain policy of the government, rather than the insufficiency of protecting duties, that unnerves the arm of the manufacturer, and paralyzes his efforts. Let him be assured of the steady patronage of government, and the difficulties that now embarrass him will soon be 
removed, his slumbering energies will be aroused, and success will crown his exertions.

The establishment of this protecting policy, has been accompanied by the most untiring and vigilant opposition, and has produced an exasperation and acerbity of fecling, unexampled in the history of our country. Time and reflection, it is believed, will allay the fever of excitement, and recal our impassioned brethren to a holier sense of the duties of patriotism, and their allegiance. Unless the present instance shall contradict all past experience, the time is at hand, when the rancorous ebullitions of the spirit of nullification shall cease, and the good old fashioned doctrine of acquiescence in the will of a majority, fairly expressed, shall be more firmly established. And unless we utterly mistake the signs of the times, the day is not far distant, when we shall all cordially approve the principles of the American System, and the South and North, the East and West heartily unite in the sentiment, that the American System is our whole country's sheet anchor, and New-England's only hope of salvation. 


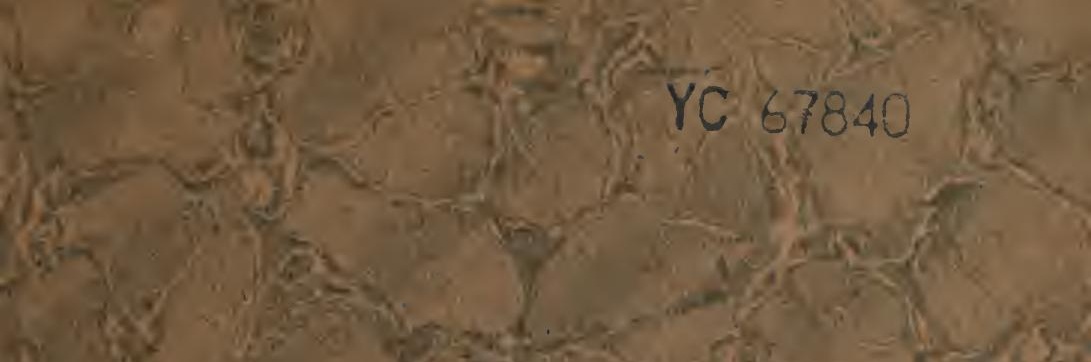
6

(2) $2 x, 3 x+18$

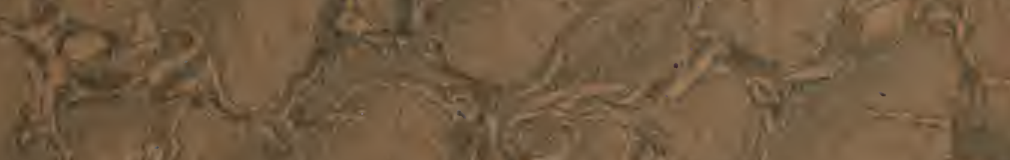

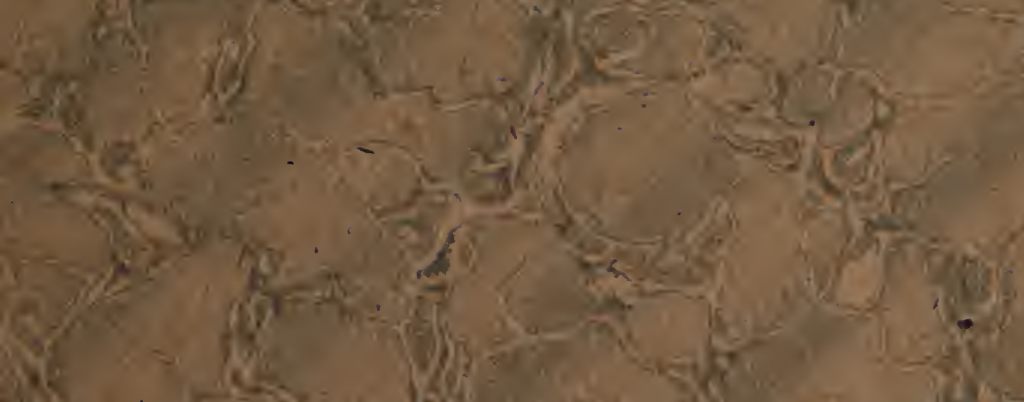

A 20 (4) biger a $3 x$ ine i)

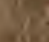
Wh (5)

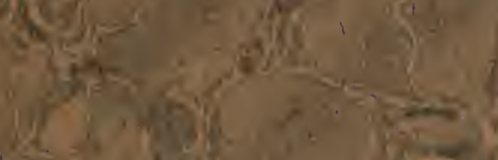
$x=70,2$ ant.

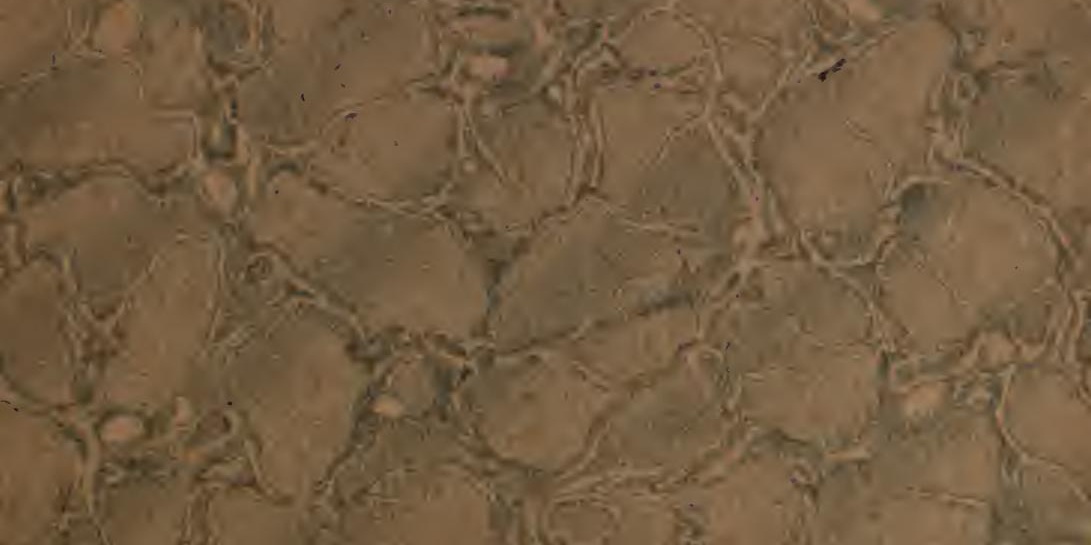




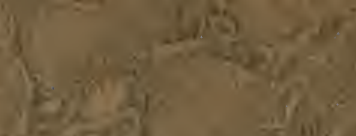

(2) $y=28$

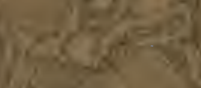

$y^{2}$

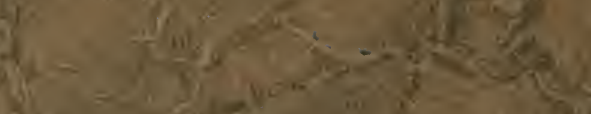

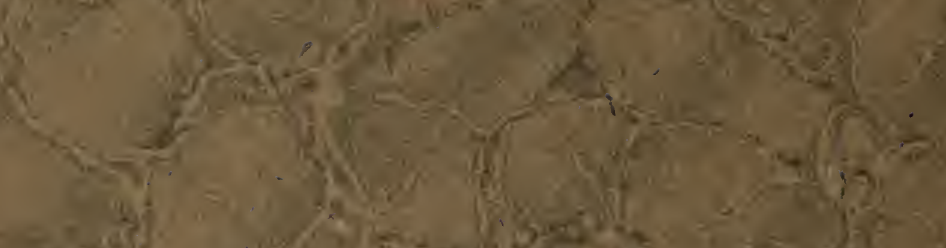

178

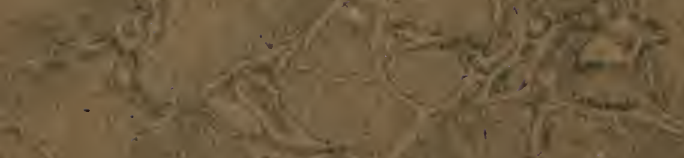

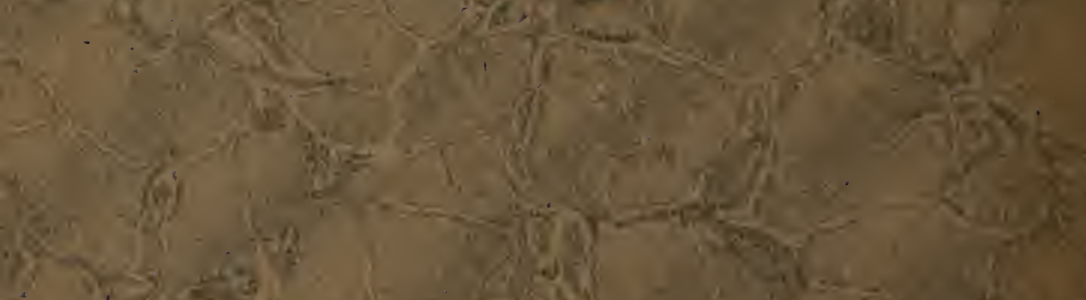

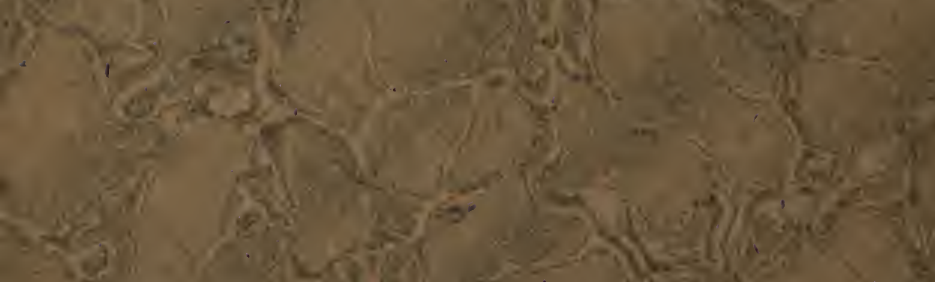

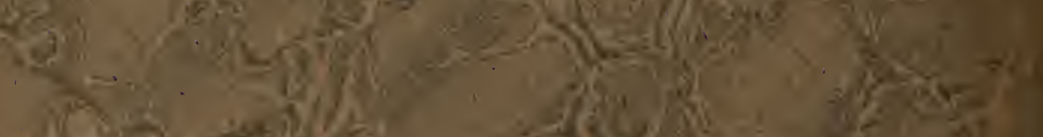

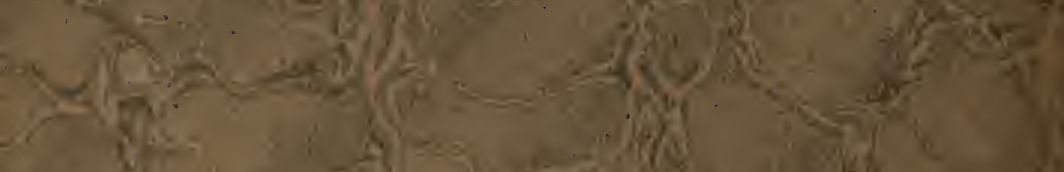

if $x^{2}$

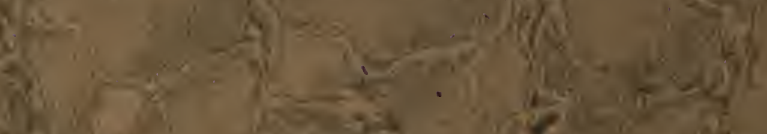

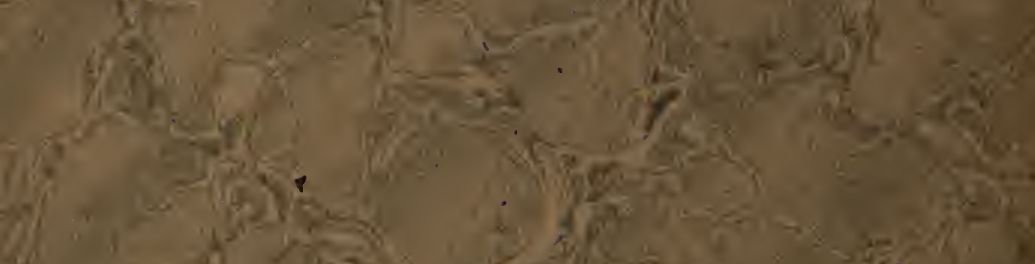

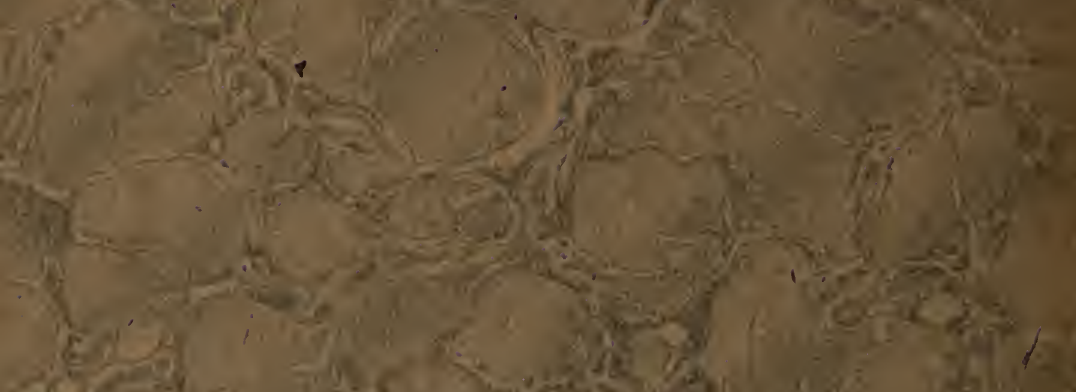

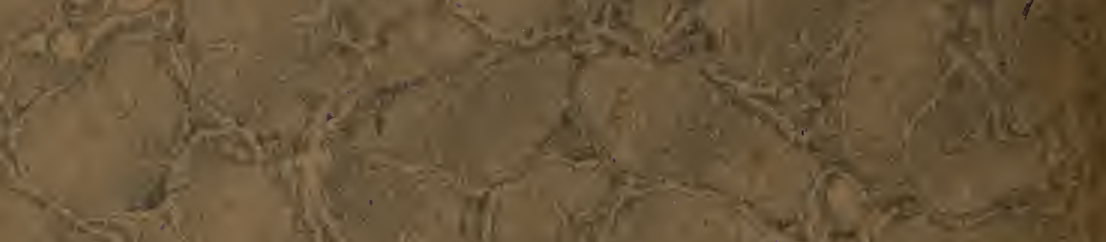
M.

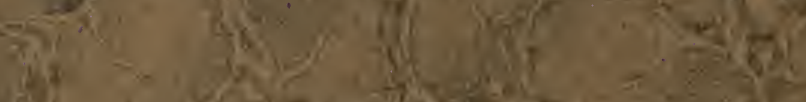

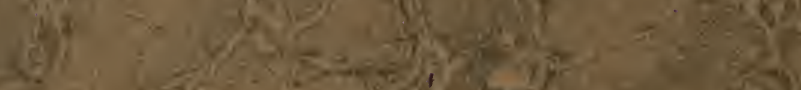

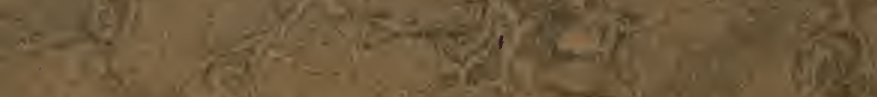

